\title{
Effect of Diet Composition on Energy Expenditure during Weight Loss: The POUNDS LOST Study
}

\author{
George A. Bray, Steven R. Smith, Lilian DeJonge, Russell de Souza, Jennifer Rood, \\ Catherine M. Champagne, Nancy Laranjo, Vincent Carey, Eva Obarzanek, Catherine M. \\ Loria, Stephen D. Anton, Donna H. Ryan, Frank L. Greenway, Donald Williamson, and \\ Frank M. Sacks \\ Pennington Biomedical Research Center Baton Rouge, LA, Harvard School of Public Health and \\ Harvard Medical School-Brigham and Women's Hospital, Boston MA and the National Heart, \\ Lung, and Blood Institute, Bethesda, MD
}

\section{Abstract}

Background-Weight loss reduces energy expenditure, but the contribution of different macronutrients to this change is unclear.

Hypothesis-We tested the hypothesis that macronutrient composition of the diet might affect the partitioning of energy expenditure during weight loss.

Design-A sub-study of 99 participants from the POUNDS LOST trial had total energy expenditure (TEE) measured by doubly labeled water and resting energy expenditure (REE) measured by indirect calorimetry at baseline and repeated at 6 months in 89 participants. Participants were randomly assigned to one of 4 diets with either $15 \%$ or $25 \%$ protein and $20 \%$ or $40 \%$ fat.

Results-TEE and REE were positively correlated with each other and with fat free mass and body fat, at baseline and 6 months. The average weight loss of $8.1 \pm 0.65 \mathrm{~kg}$ (LSmean $\pm \mathrm{SE}$ ) reduced TEE by $120 \pm 56 \mathrm{kcal} / \mathrm{d}$ and REE by $136 \pm 18 \mathrm{kcal} / \mathrm{d}$. A greater weight loss at 6 months was associated with a greater decrease in TEE and REE. Participants eating the high fat diet lost significantly more fat free mass $(1.52 \pm 0.55 \mathrm{~kg})$ than the low fat diet group $(\mathrm{p}<0.05)$. Participants eating the low fat diet had significantly higher measures of physical activity than the high fat group.

Conclusion-A greater weight loss was associated with a larger decrease in both TEE and REE. The low fat diet was associated with significant changes in fat free body mass and energy expenditure from physical activity compared to the high fat diet.

Users may view, print, copy, download and text and data- mine the content in such documents, for the purposes of academic research, subject always to the full Conditions of use: http://www.nature.com/authors/editorial_policies/license.html\#terms

Send Correspondence to: George A. Bray, M.D., Pennington Center, 6400 Perkins Road, Baton Rouge, LA 70808, (225) 763-314,

FAX (225) 763-3045, brayga@pbrc.edu.

This trial was registered at ClinTrials.gov (NCT00072995)

There were no conflicts of interest for this study. 


\section{Introduction}

Energy expenditure is affected by a number of variables, including sex, race, age, activity level and nutritional status $(1,2)$. Men generally have higher energy expenditure than women largely as a result of their larger lean body mass (3), and Caucasians have higher energy expenditure than African-Americans even after controlling for body composition $(4,5)$. Calorie restriction decreases resting and total energy expenditure (4-12). When healthy volunteers were restricted to $50 \%$ of their daily energy intake for 6 months their body weight and energy expenditure declined steadily $(7,13)$. In clinical studies in overweight or obese volunteers, weight loss is also associated with a decrease in resting energy expenditure (4, 5, 9) and total energy expenditure measured by doubly labeled water $(10,11)$.

Dfferences in energy expenditure resulting from differences in the thermic effect of macronutrients have been proposed as a mechanism to achieve better weight loss. Low carbohydrate diets have been reported to enhance weight loss in some studies (13-17) but not in others (19-21). The higher thermic effect of protein may make higher protein diets more conducive to weight loss than lower protein diets (22). However, the role of specific macronutrients in the changes of energy expenditure during weight loss have been examined in only a few studies (23-25). Thus, it is unclear whether levels of dietary fat, protein, or carbohydrate in weight loss diets might affect overall energy expenditure or the components of energy expenditure related to resting energy expenditure or physical activity.

The Preventing Overweight Using Novel Dietary Strategies (POUNDS LOST) trial is a randomized clinical trial that provided an opportunity to examine the role of macronutrients on overall energy expenditure and its components under well controlled conditions (26). In POUNDS LOST, 811 overweight or obese adults, age 30-70, were randomized at two clinical centers (Boston, MA and Baton Rouge, LA) to one of 4 diets that differed in protein and fat. Resting energy expenditure and total energy expenditure were measured in a subsample of 99 participants at baseline and repeated in 89 participants after 6 months of dietary treatment for weight loss. This paper reports the findings of the doubly-labeled water sub-study, and compares the data to calculations of TEE and REE recommended in the scientific literature.

\section{Methods and Materials}

\section{Subjects}

The 99 adults in this sub-study were recruited from the participants in the POUNDS LOST Study site in Baton Rouge, LA (26). These volunteers were randomized to diet assignment, and each participant signed a consent form approved by the Pennington Biomedical Research Center Institutional Review Board. This trial was registered at clinicaltrials.gov (NCT00072995)

\section{Protocol}

The design, dietary intervention, and results of the main study have been published (26). Briefly, at the completion of screening and baseline measurements volunteers were randomly assigned to one of four dietary treatment groups, using a factorial design of high 
$(40 \%=\mathrm{HF})$ or low $(20 \%=\mathrm{LF})$ fat with high $(25 \%=\mathrm{HP})$ or average protein $(15 \%=\mathrm{AP})$. The volunteers were initially given individually instruction in their dietary plan by a registered dietitian and then met weekly in groups according to their assigned diet or in individual sessions with a dietary counselor for 6 months. Participants in all 4 diet groups received similar information about lifestyle modification in a standard form, including engaging in moderate-intensity physical activity for 90 minutes per week. Initial measurements of DLW in the sub-group of 99 participants were done prior to beginning the diets. The 6 month DLW measurements were done while the subjects were still instructed to consume their assigned diets, although weight loss had reached a plateau by this time (26).

\section{Anthropometry and the Baecke Physical Activity Questionnaire}

Height and weight were measured in the morning after a 12 hour overnight fast. Physical activity was assessed by the Baecke self-reported questionnaire from which we derived a physical activity factor (27) that was multiplied by measured resting energy expenditure to calculate the energy level of the prescribed diet for each participant.

\section{Total Energy Expenditure (TEE)}

Total energy expenditure (TEE) was determined by doubly-labeled water. Two baseline urine samples and a fasting blood sample were obtained for assessment of background levels of stable isotopes. Then a mixture of $1 \mathrm{~g}$ of ${ }^{2} \mathrm{H}_{2} \mathrm{O}$ (99.99\% enrichment) and $190 \mathrm{~g}$ of $10 \%$ enrichmed $\mathrm{H}_{2}{ }^{18} \mathrm{O}$ was given to each participant at a dose of $2.2 \mathrm{~g} / \mathrm{kg}$ total body water determined from dual-energy x-ray absorptiometry (DXA) measurements. Urine samples were collected 1.5, 3, 4, 5, and 6 hours after the dose. Two additional urine samples were collected on day 7 and day 14, for a total of 10 samples. The food quotient (FQ) obtained from the dietary records (28) at baseline and 6 months was used to calculate energy expenditure from the measurements of doubly-labeled water rather than the RQ since we did not have RQ values that reflected the actual dietary intakes and because FQ has been shown to be a reliable surrogate (29).

\section{Resting Energy Expenditure (REE)}

Resting energy expenditure (REE) was determined in the morning by indirect calorimetry after a 12 hour overnight fast. After resting quietly for 30 minutes, a transparent plastic hood connected to the device was placed over the head of the participant, who remained motionless and awake during the test period. Oxygen consumption and carbon dioxide production were measured with a Delta Trac II Metabolic cart (Datex-Ohmeda, Helsinki, Finland) during the last 20 minutes. The respiratory quotient (RQ or $\mathrm{R}$ ) was determined from continuous measurements of $\mathrm{O}_{2}$ and $\mathrm{CO}_{2}$ concentrations in inspired and expired air diluted with a constant air flow ( $40 \mathrm{~L} / \mathrm{min})$ generated by the metabolic cart. The respiratory quotient (RQ) is the ratio of $\mathrm{CO}_{2} / \mathrm{O}_{2}$ and is used to calculate energy expenditure.

\section{Calculated Data and Statistics}

Metabolic Rate-Calculations of metabolic rate were done using Weir equation \# 7 (30) which includes protein $\left\{\mathrm{K}=3.941+1.106 \mathrm{R} /(1+0.082 \mathrm{p})\right.$, where $\mathrm{K}$ is the $\mathrm{kcal} / \mathrm{LO}_{2}$ liberated, $\mathrm{R}$ is the non-protein respiratory quotient [food quotient (FQ) was substituted at baseline and 
6 months (29)] and $\mathrm{p}$ is the dietary protein fraction of energy $\}$. In this equation the protein correction is $1 \%$ when $12.3 \%$ of calories arise from protein. The food quotient (FQ) was calculated with the following formula: Food Quotient $(\mathrm{FQ})=[1.0 *(\%$ Carbohydrate $/ 100)]+$ $[0.7 *(\%$ fat $/ 100)]+[0.79 *(\%$ protein $/ 100)]+[0.66 * \%$ alcohol $/ 100)](28)$.

Fat free mass (FFM) was calculated at baseline and 6 months using the average of the deuterium and oxygen-18 distribution spaces and the constants of 1.041 for deuterium space and 1.007 for oxygen-18 space and dividing them by 0.73 (32). Body fat was body weight minus FFM. Surface area was $0.007284[\mathrm{ht}(\mathrm{cm})]^{0.725}[\mathrm{Wgt}(\mathrm{kg})]^{0.425}$ (33). Body Energy

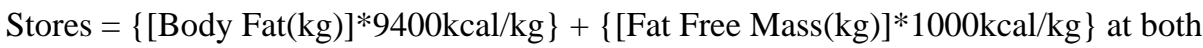
baseline and 6 months, and the change in energy stores is the difference between these two numbers

\section{Statistical Analysis}

Baseline characteristics are expressed as mean $\pm \mathrm{SD}$ and the differences between men and women compared by analysis of variance using t-tests for continuous variables and Fisher's exact test for nominal level variables. Changes from baseline were analyzed by analysis of covariance using the fit model program in JMP-7 with baseline variables as the covariate and adjusted for baseline sex and age. Regression analysis was used to compare the slopes of the regression of TEE and RE on fat and fat-free mass between men and women at baseline. General linear model analysis of variance was used to compare outcomes after weight loss. The changes by diet groups used the main effects of difference in $40 \mathrm{en} \%$ fat $($ High Fat $=\mathrm{HF})$ versus $20 \mathrm{en} \%$ fat $($ Low Fat $=\mathrm{LF})$ or the $15 \mathrm{en} \%$ average protein $(\mathrm{AP})$ versus the 25 en\% high protein (HP) diets with the baseline variable as a covariate and adjusted for baseline age and sex. Contrasts between diet groups were compared using Tukey-Kramer method. All calculations were done using JMP7.0 (SAS Institute, Cary, NC). Data are expressed as mean $\pm \mathrm{SD}$ for baseline data and LS mean $\pm \mathrm{SE}$ for change from baseline.

\section{Results}

\section{Baseline Participant Data}

Table 1 presents baseline characteristics of the 99 participants. The men were significantly taller, and heavier and had higher total and resting energy expenditure and more fat free mass and lower percent body fat than women. Compared to the entire study population there was a greater proportion of men in this sub study (49\%) than in the overall trial (36.5\%), and a higher percentage of whites (92\%) than in the overall trial (82\%). The sub-study participants were older (53.2 yr vs. $50.7 \mathrm{yr} \mathrm{p}=0.011$ ), and had a borderline difference in Baecke activity factor ( $\mathrm{p}=0.053$ ). There were no differences in baseline TEE, REE, PAL or PAEE across the 4 diet groups (All;'s >0.40)(data not shown).

\section{Baseline Energy Expenditure}

Total and resting energy expenditure was significantly higher in men than women ( $<<0.0001)$ even after adjustment for FFM which made the difference in TEE smaller [2864 $\pm 57 \mathrm{kcal} / \mathrm{d}$ in men; $2607 \pm 58 \mathrm{kcal} / \mathrm{d}$ in women $(\mathrm{p}=0.0091)]$. The activity factor from 
the Baecke questionnaire and the physical activity level (PAL) did not differ between men and women, but men had a significantly higher energy expenditure from physical activity (PAEE) than women ( $\mathrm{p}=0.027)$. The prescribed daily energy deficit was larger than planned in the protocol (945 kcal/d actual vs. $750 \mathrm{kcal} / \mathrm{d}$ planned). Baseline TEE was positively and significantly associated with both FFM and fat in men and in women (Figure 1). In simple regression models using baseline data, FFM explained $67 \%$ of the variance in TEE, and was a better univariate predictor than surface area (55\% of variance) total body weight (50\% of variance) or BMI (19\% of variance). FFM was a significant predictor of REE accounting for $69 \%$ of the variance in men ( $\mathrm{p}<0.001)$ and $42 \%$ in women ( $\mathrm{p}<0.001)$. FFM explained $75 \%$ of the variance in REE, compared to $69 \%$ for surface area $65 \%$ for total body weight and $26 \%$ for BMI. Body fat explained $16 \%$ of the variance in REE in men $(\mathrm{p}=0.0038)$ and $29 \%$ in women ( $\mathrm{p}=0.0001)$. The relationship between baseline REE and body fat remained significant in women after adjustment for FFM $(\beta=5.1 \pm 1.4 ; \mathrm{p}=0.0007)$, but not in men $(\mathrm{p}=0.30)$.

\section{Changes in energy expenditure after weight loss}

The 6-month changes from baseline in body weight, body composition, and the measured components of energy expenditure are summarized in Table 2. Ten participants (10\%) did not complete the second measurement of doubly labeled water and the changes from baseline only included those individuals with information at baseline and 6 months. At 6 months, body weight, surface area and BMI decreased significantly from baseline $(\mathrm{P}<0.05)$, but the change was not different between men and women. Weight loss was not significantly different between men and women after adjusting for baseline weight $(\mathrm{p}=0.45)$. Both body fat $(\mathrm{p}=0.23)$ and fat free mass $(\mathrm{p}=0.041)$ decreased significantly after weight loss. Nonresting energy expenditure $[\mathrm{NREE}=($ TEE minus REE $)]$ increased in men and decreased in women. In unadjusted models, the change in TEE and was not related to the change in REE, but after adjustment for baseline values they were strongly related $(\mathrm{p}=0.0008)$.

At 6 months, both TEE and REE had decreased in men and women and these changes were positively and significantly related to the decrease in FFM ( $p<0.0001)$ (Figure 2). Higher baseline body weight, higher BMI, more FFM and larger amounts of body fat were all significant $(\mathrm{p}<0.05)$ predictors of weight loss.

\section{Effect of Diet on Energy Expenditure and Body Composition after Weight Loss}

Table 3 shows the changes in energy expenditure and body composition from baseline for each of the two main dietary contrasts - high fat versus low fat and average protein versus high protein. The baseline FQ was $0.838 \pm 0.023$ and decreased significantly more in the low fat diet (Table 3) but was not significant different between the two protein diets. Fat free mass decreased by $1.52 \pm 0.54 \mathrm{~kg}$ in the high fat diet compared to a small increase of $+0.20 \pm 0.55 \mathrm{~kg}$ in the low fat group ( $\mathrm{p}<0.05$ ). There was a significant difference in the energy expenditure related to physical activity (PAEE), the non-resting energy expenditure (NREE) and the physical activity level (PAL) between the high and low fat diet groups $(p<0.05)$. As the percentage of carbohydrate in the assigned increased, the PAEE, PAL and NREE each increased. This is illustrated in Figure 3 for the PAEE. In contrast to the effects of different levels of dietary fat, there was no significant relationship between the two levels 
of dietary protein ( $25 \mathrm{en} \%$ or $15 \mathrm{en} \%$ ) on any of the estimates of physical activity or body composition.

\section{Discussion}

This study tested the hypothesis that the macronutrient composition of the diet would affect energy expenditure or body composition during weight loss. The data show that there were modest differences between the low fat and high fat diets, but no significant differences between the average and high protein diets. In addition there were the expected differences related to weight loss and gender.

Differences between the thermic effect of protein, carbohydrate, and fat led to the hypothesis that dietary composition might affect energy expenditure (20,35). Mikkelsen et al (23) found that substituting either animal protein (pork) or soy protein for carbohydrate increased energy expenditure by $3 \%$ in mildly obese men over $24 \mathrm{~h}$ in a respiration calorimeter. In a second study, Whitehead et al (23) examined the effect of $15 \%$ or $35 \%$ protein intake on 24$\mathrm{h}$ energy expenditure during an energy restricted diet and found that on a high protein diet, the energy decrease was $71 \mathrm{kcal} / \mathrm{d}$ smaller. In a short study lasting 19-21 days, Bandini et al found that TEE was significantly higher with a very high carbohydrate $(83.1 \%)$ diet than a very high fat $(83.5 \%)$ diet, but REE was the same suggesting lower physical activity on the high fat diet (25). Racette et al compared a low fat versus a low carbohydrate diet with or without exercise in a small study of 23 women that lasted 12 weeks. Resting energy expenditure declined comparably in the 2 diet groups (36). In the POUNDS Lost sub-study the food quotient (FQ) had a small decrease in each group during weight loss, in spite of the fact that some of the diets had more than 50\% carbohydrate. This may be due to the fact that the subjects were in negative calorie balance, and thus drawing fat from their fat stores. There was a significant decrease of $1.52 \mathrm{~kg}$ in fat free body mass in those eating the low fat diet compared to the high fat diet groups. There was also a significantly higher level of energy expenditure from physical activity, a higher physical activity level (PAL), and a higher non-resting energy expenditure with the low fat diet. Since the low fat diets are the ones with the higher carbohydrate, this suggests that the higher carbohydrate diets may provide the carbohydrate fuel needed for physical activity more readily than the lower carbohydrate diets.

After weight loss, TEE declined by $120 \mathrm{kcal} / \mathrm{d}$ and REE by $136 \mathrm{kcal} / \mathrm{d}$. The decrease of REE and TEE was smaller than the decrease reported in several other studies $(5,10,11)$, which range from 150 to $250 \mathrm{kcal} /$ day for TEE $(10,11)$ and 180 to $275 \mathrm{kcal} /$ day for $\operatorname{REE}(5,10)$. However, the $8.5 \%$ weight loss in the POUNDS Lost trial is smaller than in many of these studies which ranged from $16 \%$ to $27 \%$, and this probably accounts for the differences. However, the $8.4 \%$ decrease in REE in Pounds Lost participants is similar to that reported for a similar weight loss by Foster et al (9.7\% in black women and $6.3 \%$ in white women) (4).

The physical activity level of our participants was in the normal range (43) and was similar to the study by Amatruda et al (10) PAL 1.68 to 1.81). The PAL increased slightly, but significantly in those eating the low fat diet. The exercise prescription for all participants in 
the POUNDS Lost trial was designed to maintain 90 min of exercise per week. In spite of this, our data suggest that those eating the low fat diet increased their physical activity more as they lost weight more than those eating the high fat diet. The data of Amatruda et al (9) differ from ours by showing a modest decrease in physical activity.

This study called for a deficit of $750 \mathrm{kcal} / \mathrm{d}$ which was calculated from baseline REE multiplied by an activity factor which averaged 1.56 (27). This is lower than the measured physical activity level (PAL) of 1.71. (see Table 1). Thus, the energy deficit using the Baecke activity factor was, on average, $195 \mathrm{kcal} / \mathrm{d}$ lower than observed, which accounted for the higher prescribed energy level of $945 \mathrm{kcal} / \mathrm{d}$ rather than the planned $750 \mathrm{kcal} / \mathrm{d}$ reduction. We know from other studies that self-report of activity factors, particularly in men, may be problematic (36) and may account for discrepancies in estimating actual energy needs.

The observed decrease in body energy stores was over $73 \mathrm{Mcal}$. If participants had adhered to their diets the energy loss should have been over $170 \mathrm{Mcal}$. The actual loss was thus less than $50 \%$ of the expected loss, suggesting that our participants were adhering to only about half of the prescribed energy deficit. This problem of adherence was noted in our main study (26) and in other studies with diet (17, 19, 37-42).

The measurements of TEE and REE at baseline were compared to data on REE, TEE, PAL and PAEE calculated from published formulas $(1,34)$ (Supplemental Table). Although small differences were detected, some of which were statistically significant, these prediction equations were reasonably close to our measured data. The measured TEE, for example was $245 \mathrm{kcal} / \mathrm{d}$ lower in men $(\mathrm{p}<0.0001)$ and $107 \mathrm{kcal} / \mathrm{d}$ lower in women $(0=0.0040)$ than calculated from the Institute of Medicine equations (IOM)(1). The measured REE was closer to the calculated values in men $(81 \mathrm{kcal} / \mathrm{d} \mathrm{p}=0.049)$ and in women $(36 \mathrm{kcal} / \mathrm{d} \mathrm{p}=0.31)(34)$. Estimates of the physical activity level (PAL=TEE/REE) in women were close (1.75 vs 1.72), but for men, the measured value of 1.71 was only slightly lower than the calculated one (1.72) and close to those of Westerterp and Speakman (43).

This is the largest study to examine the effect of weight loss and macronutrient composition on energy expenditure in both overweight or obese men and women where both resting energy expenditure (REE) and total energy expenditure (TEE) were measured at baseline and again after 6 months. One strength of this study is that it provides direct measures of both TEE and REE at baseline and again 6 months after consuming 4 diets differing in macronutrient composition. Second, the size of the sample was relatively large with nearly 100 people at baseline and had nearly $40 \%$ men. Nearly $90 \%$ completed the DLW protocol at 6 months. A major weakness is the uncertainly about the degree of adherence to the prescribed diets (26). We have tried to partly address this problem by using the Food Quotient measured from dietary intake in place of the RQ when calculating energy expenditure Also, this sub-study was recruited from only one of the two clinical centers and was thus not a random sample of the study population.

In summary, weight loss was associated with a decrease in total energy expenditure and resting energy expenditure in men and women. Almost all of the decrease in TDEE was 
contributed by the decrease in REE. Changes in resting energy expenditure after weight loss were largely a function of weight loss. FFM increased significantly more on the low fat diet than the high fat diet. Measures of physical activity were higher in participants eating the low fat diet compared to the high fat diet.

\section{Supplementary Material}

Refer to Web version on PubMed Central for supplementary material.

\section{Acknowledgement}

The Pounds Lost study was designed by Dr. Frank Sacks and Dr. George Bray. The double-labeled water sub-study was designed by Dr. George Bray and refined by Drs. Steven Smith, Jennifer Rood, Donna Ryan, and Eva Obarzanek. The manuscript was drafted by George Bray and revised by all authors, and all authors take responsibility for its content.

This study was supported by grant HL-073286 from the National Heart, Lung, and Blood Institute, National Institutes of Health. We thank the participants in the trial for their dedication and contribution to the research. We thank the following research staff members for their assistance in conducting the trial: Jungnam Joo, Ph.D. and Charlotte A. Pratt, Ph.D. at National Heart, Lung, and Blood Institute; Patricia Copeland, M.S., R.D. at Harvard School of Public Health; Cassandra Carrington, Jacqueline Gallagher, Clota Heazel, Megan Reddy, Alison Barr, M.S.,R.D., Mary Dinehart, M.S.,R.D., Marit Pywell, R.D., Dawn Quintino, M.S., R.D., Audrey Shweky, M.S.,R.D., Benjamin Harshfield, and Melissa Mcnery-Stonelake at Brigham \& Women's Hospital; Frank L. Greenway, MD, Julia St. Amant, Elizabeth Tucker, Heidi K. Millet, Marisa M. Smith. Sara J. Schoen, RD, LDN, Betsy B. Bernhard, Courtney Brock, R.D., Laura DeCuir Moran, R.D., Katherine Lastor, R.D., Erma Levy, M.P.H., R.D., Lisa Miller R.D., Gina Pennington R.D., Dana Vieselmeyer, M.P.H., R.D., Marlene Afton, Lindsay Coates, Dawn Turner, Richard Dale Achord, Bridget Conner, Margaret Graves, Doris Hoffpauir, Carla Kimmel, Steve Lee, Kelli Melancon, Sandra Richard, Stacey Roussel, Elizabeth Soroe, Denise Stein, Jamie Tuminello, Ray Allen, Eric LeBlanc and Connie Murla at the Pennington Biomedical Research Center. We thank the members of the Data and Safety Monitoring Board: Barbara V. Howard, Ph.D. (Chair), Phyllis E. Bowen, PhD, Daniel W. Jones, MD, Michael G. Perri, PhD, David M. Reboussin, PhD, and Marcia L. Stefanick, PhD.

Supported by Grant: HL-073286 from the National Heart, Lung, and Blood Institute, National Institutes of Health

\section{References}

1. Dietary Reference Intakes. National Academies Press; Washington DC: 1997-2002.

2. Ravussin E, Lillioja S, Anderson TE, Christin L, Bogardus C. Determinants of 24-hour energy expenditure in man. Methods and results using a respiratory chamber. J Clin Invest. 1986; 78:156878. [PubMed: 3782471]

3. Tooze JA, Schoeller DA, Subar AF, Kipnis V, Schatzkin A, Troiano RP. Total daily energy expenditure among middle-aged men and women: The OPEN Study. AJCN. 2007; 86:382-387.

4. Foster GD, Wadden TA, Swain RM, Anderson DA, Voge RA. Changes in resting energy expenditure after weight loss in obese African-American and white women. Am J Clin nutr. 1999; 69:13-17. [PubMed: 9925117]

5. Weinsier RL, Hunter GR, Zuckerman PA, Redden DT, Darnell BE, Larson DE, Newcomer BR, Goran MI. Energy expenditure and free-living physical activity in black and white women: comparison before and after weight loss. Am J Clin Nutr. 2000; 71:1138-1146. [PubMed: 10799376]

6. Benedict, FG. A Study of Prolonged Fasting. Carnegie Institution of Washington; Washington: 1915. Publicaiton no 203

7. Keys, A.; Brozek, J.; Henschel, A.; Mickelsen, O.; Taylor, HL. The Biology of Human Starvation. The University of Minnesota Press; Minneapolis: 1950.

8. Bray GA. Effect of caloric restriction on energy expenditure in obese patients. Lancet. 1969; 2:397398. [PubMed: 4184486] 
9. Leibel RL, Rosenbaum M, Hirsch J. Changes in energy expenditure resulting from altered body weight. N Engl J Med. 1995; 332:621-8. [PubMed: 7632212]

10. Amatruda JM, Statt MC, Welle SL. Total and resting energy expenditure in obese women reduced to ideal body weight. J Clin Invest. 1993; 92:1236-1242. [PubMed: 8376583]

11. Walsh MC, Hunter GR, Sirkul B, Gower BA. Comparison of self-reported with objectively assessed energy expenditure in black and white women before and after weight loss. Am J Clin Nutr. 2004; 79:1013-1019. [PubMed: 15159231]

12. Redman L, et al. Redman LM, Heilbronn LK, Martin CK, Alfonso A, Smith SR, Ravussin E, Pennington CALERIE Team. Effect of calorie restriction with or without exercise on body composition and fat distribution. J Clin Endocrinol Metab. Mar; 2007 92(3):865-72. JAMA 2008. [PubMed: 17200169]

13. Dulloo AG, Jacquet J. The control of partitioning between protein and fat during human starvation: its internal determinants and biological significance. Br J Nutr. 1999; 82:339-56. [PubMed: 10673906]

14. Foster GD, Wyatt HR, Hill JO, McGuckin BG, Brill C, Mohammed BS, Szapare PO, Rader DJ, Edman JS, Klein S. A randomized trial of a low-carbohydrate diet for obesity. NEJM. 2003; 348:2082-2090. [PubMed: 12761365]

15. Samaha FF, Iqbal N, Seshadri P, Chicano KL, Daily DA, McGrory J, Williams T, Williams M, Gracely EJ, Stern L. A low-carbohydrate as compared with a low-fat diet in severe obesity. N Engl J Med. 2003; 348:2074-81. [PubMed: 12761364]

16. Brehm BJ, Seeley RJ, Daniels SR, D’Alessio DA. A randomized trial comparing a very low carbohydrate diet and a calorie-restricted low fat diet on body weight and cardiovascular risk factors in healthy women. J Clin Endocrinol Metab. 2003; 88:1617-23. [PubMed: 12679447]

17. Gardner CD, Kiazand A, Alhassan S, Kim S, Stafford RS, Balise RR, Kraemer HC, King AC. Comparison of the Atkins, Zone, Ornish, and LEARN diets for change in weight and related risk factors among overweight premenopausal women: the A TO Z Weight Loss Study: a randomized trial. JAMA. 2007; 297:969-77. [PubMed: 17341711]

18. Shai I, Schwarzfuchs D, Henkin Y, Shahar DR, Witkow S, Greenberg I, Golan R, Fraser D, Bolotin A, Vardi H, Tangi-Rozental O, Zuk-Ramot R, Sarusi B, Brickner D, Schwartz Z, Sheiner E, Marko R, Katorza E, Thiery J, Fiedler GM, Blüher M, Stumvoll M, Stampfer MJ, Dietary Intervention Randomized Controlled Trial (DIRECT) Group. NEJM Weight loss with a lowcarbohydrate, Mediterranean, or low-fat diet. N Engl J Med. 2008; 359:229-41. [PubMed: 18635428]

19. Dansinger ML, Gleason JA, Griffith JL, Selker HP, Schaefer EJ. Comparison of the Atkins, Ornish, Weight Watchers, and Zone diets for weight loss and heart disease risk reduction: a randomized trial. JAMA. 2005; 293:43-53. [PubMed: 15632335]

20. Noakes M, Keough JB, Foster PR, Clifton PM. Effect of an energy-restricted, high-protein, low-fat diet relative to a conventional low-fat, high-carbohydrate diet on weight loss, body composition, nutritional status, and markers of cardiovascular health in obese women. Am J Clin Nutr. 2005; 81:1298-1306. [PubMed: 15941879]

21. Lecheminant JD, Gibson CA, Sullivan DK, et al. Comparison of a low carbohydrate and low fat diet for weight maintenance in overweight or obese adults enrolled in a clinical weight management program. Nutr J. 2007; 6:36. [PubMed: 17976244]

22. Eisenstein J, Roberts SB, Dallal G, Saltzman E. High-protein weight-loss diets: are they safe and do they work? A review of the experimental and epidemiologic data. Nutr Rev. 2002; 60(7 Pt 1): 189-200. Review. [PubMed: 12144197]

23. Mikkelsen PB, Toubro S, Astrup A. Effect of fat-reduced dies on 24-h energy expenditure: comparisons between animal protein, vegetable protein and carbohydrate. Am J Clin Nutr. 2000; 72:1135-1141. [PubMed: 11063440]

24. Whitehead JM, McNeill G, Smith JS. The effect of protein intake on 24-h energy expenditure during energy restriction. Intern J Obes Relat Metab Disord. 1996; 20:727-732.

25. Bandini LG, Schoeller DA, Diez WH. Metabolic differences in response to a high-fat vs a highcarbohydrate diet. Obes Res. 1994; 2:348-354. [PubMed: 16358395] 
26. Sacks FM, Bray GA, Carey VJ, Smith SR, Ryan DH, Anton SD, McManus K, Champagne CM, Bishop LM, Laranjo N, Leboff MS, Rood JC, de Jonge L, Greenway FL, Loria CM, Obarzanek E, Williamson DA. Comparison of weight-loss diets with different compositions of fat, protein, and carbohydrates. N Engl J Med. Feb 26; 2009 360(9):859-73. [PubMed: 19246357]

27. Baecke JAH, Burema J, Frijters JER. A short questionnaire for the measurement of habitual physical activity in epidemiological studies. Am J Clin Nutr. 1982; 36:936-942. [PubMed: 7137077]

28. Toubro S, Sorensen TIA, Hindsberger C, Christensen NJ, Astrup A. Twenty-four-hour respiratory quotient: The role of diet and familial resemblance. J Clin Endocrinol Metab. 1998; 83:27582764. [PubMed: 9709943]

29. Black AE, Prentice AM, Coward WA. Use of food quotients to predict respiratory quotients for the doubly-labeled water method of measuring energy expenditure. Hum Nutr Clin Nutr. 1986; 40C: 381-391. [PubMed: 3771290]

30. Weir JB. New method of calculating metabolic rate with special reference to protein metabolism. J Physiol. 1949; 109:1-9. [PubMed: 15394301]

31. Racette SB, Schoeller DA, Luke AH, Shay K, Hnilicka J, Kushner RF. Relative dilution spaces of 2H- and 18O-labeled water in humans. Am J Physiol. Oct; 1994 267(4 Pt 1):E585-590. or another reference for the appropriate dilution space ratios. [PubMed: 7943308]

32. Pace N, Rathbun EN. Studies on body composition: body water and chemically combined nitrogen content in relation to fat content. J Biol Chem. 1945; 158:685-691.

33. Bray, GA. The Obese Patient. Saunders; Philadelphia: 1976. p. 9

34. Mifflin MD, St Jeor ST, Hill LA, Scott BJ, Daugherty SA, Koh YO. A new predictive equation for resting energy expenditure in healthy individuals. Am J Clin Nutr. 1990; 51:241-7. [PubMed: 2305711]

35. Schoeller DA, Buchholz AC. Energetics of obesity and weight control: does diet composition matter? J Am Diet Assn. 2005; 105(Suppl 1):S24-S28.

36. Racette SB, Schoeller DA, Kushner RF, Neil KM, Herling-Iaffaldano K. Effects of exercise and dietary carbohydrate on energy expenditure and body compositio during weight reduction in obese women. Am J Clin Nutr. 1995:486-494. [PubMed: 7872211]

37. Heymsfield SB, Harp JB, Reitman ML, Beetsch JW, Schoeller DA, Erondu N, Pietrobelli A. Why do obese patients not lose more weight when treated with low-calorie diets? A mechanistic perspective. Am J Clin Nutr. 2007; 85:346-354. [PubMed: 17284728]

38. Trabulsi J, Schoeller DA. Evaluation of dietary assessment instruments against doubly labeled water, a biomarker of habitual energy intake. Am J Physiol Endocrinol Metab. 2001; 281:E891E899. [PubMed: 11595643]

39. Lichtman SW, Pisarska K, Berman ER, Pestone M, Dowling H, Offenbacher E, Weisel H, Heshka S, Matthews DE, Heymsfield SB. Discrepancy between self-reported and actual caloric intake and exercise in obese subjects. N Engl J Med. 1992; 327:1893-8. [PubMed: 1454084]

40. Schoeller DA. Balancing energy expenditure and body weight. Am J Clin Nutr. 1998; 68(Suppl): 956S-961S. [PubMed: 9771879]

41. Lin PH, Proschan MA, Bray GA, Fernandez CP, Hoben K, Most-Windhauser M, Karanja N, Obarzanek E, DASH Collaborative Research Group. Estimation of energy requirements in a controlled feeding trial. Am J Clin Nutr. 2003; 77:639-645. [PubMed: 12600854]

42. Prentice AM, Black AE, Coward WA, Cole TJ. Energy expenditure in overweight and obese adults in affluent societies: an analysis of 319 doubly-labeled water measurements. Eur J Clin Nutr. 1996; 50:93-7. [PubMed: 8641251]

43. Westerterp KR, Speakman JR. Physical activity energy expenditure has not declined since the 1980s and matches energy expenditures of wild mammals. Int J Obes. 2008; 32:1256-1263. 

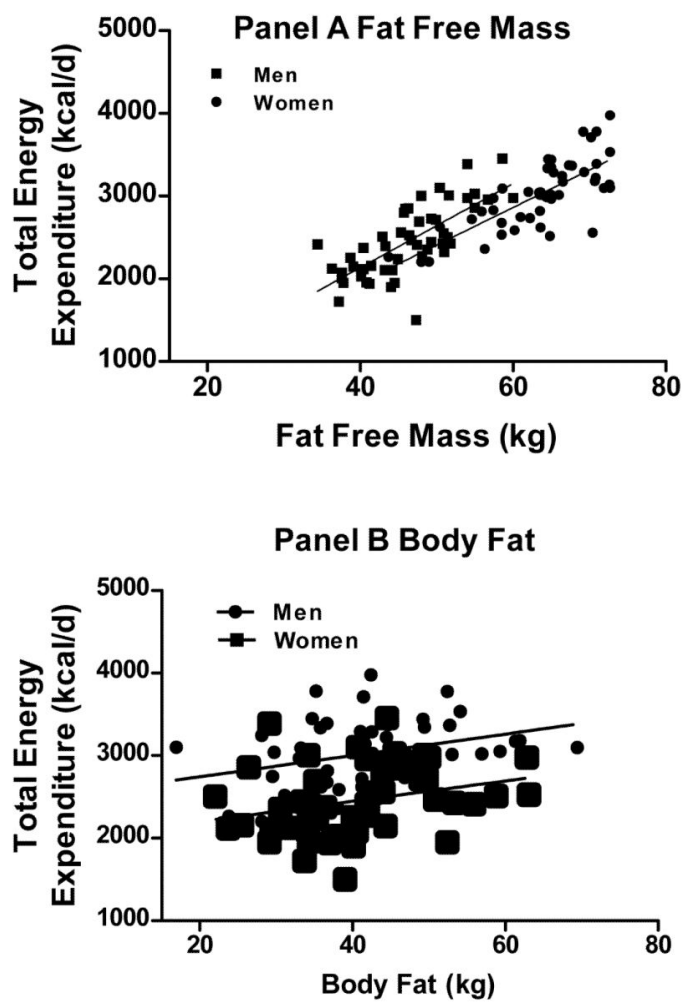

Figure 1.

Relation of Baseline TEE to Fat Free Mass and Body Fat. Lines show data for men and women plotted separately. (Panel A: $\{$ Men: baseline tdee $=138.6+45.39 *$ Bsln FFM $(\mathrm{kg})$ $(\mathrm{TBW} / 0.73)(\mathrm{p} .0001)\}\{$ Women: baseline tdee $=102.4+50.81 * \mathrm{~B} \sin \mathrm{FFM}(\mathrm{kg})(\mathrm{TBW} / 0.73)$ $(\mathrm{p}<0.0001)\}($ Panel B: Men: $\{$ baseline tdee $=2485.6+12.91 *$ Bsln Fat $(\mathrm{kg})(\mathrm{p}=0.022)\}$ Women: $\{$ baseline tdee $=1954.6+12.31 *$ Bsln Fat $(\mathrm{kg})(\mathrm{P}=0.053)\}$

Footnote: TEE was positively associated with FFM (for men, TEE = $138 \pm 45.4 * \mathrm{FFM}(\mathrm{kg})$; $\left.\mathrm{R}^{2}=0.56, \mathrm{p}<0.0001\right)$ and for women, TEE $\left.=102 \pm 50.8 * \mathrm{FFM}(\mathrm{kg}) ; \mathrm{R}^{2}=0.52, \mathrm{p}<0.0001\right)$ and with body fat (for men, TEE $=2486 \pm 12.9 * \mathrm{Fat}(\mathrm{kg}) ; \mathrm{R}^{2}=0.086, \mathrm{p}=0.023$ ) and for women, TEE $=1955 \pm 12.3 *$ Fat $\left.(\mathrm{kg}) ; \mathrm{R}^{2}=0.056, \mathrm{p}=0.053\right)$. The relationship of TEE and body fat was eliminated after adjusting for baseline FFM in both women and men. The $\mathrm{R}^{2}$ for REE vs FFM was 0.68 for men $(p<0.001)$ and 0.40 for women $(p<0.001)$ and the $R^{2}$ for REE vs body fat was 0.15 for men $(p=0.038)$ and 0.27 for women $(p<0.001)$ 
Relation of Change in Body Weight to Change in REE

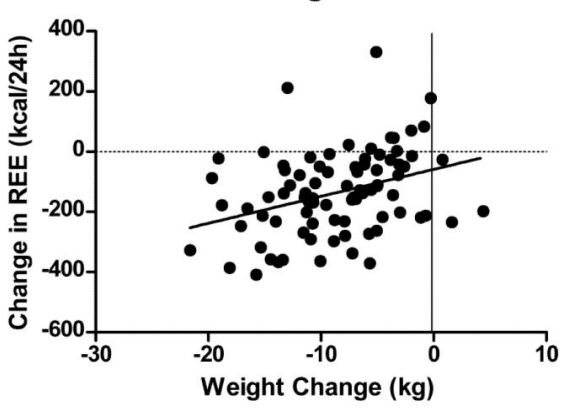

Relation of Change in Body Weight to Change in TEE

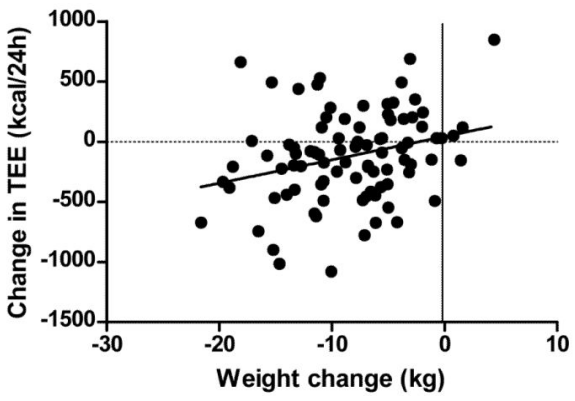

Figure 2.

Relation of change in Body Weight to Change in Resting Energy Expenditure (REE) and total Daily Energy Expenditure (For Fat: Men: $\{$ baseline EE $=85.8+27.2 *$ Bsln FFM (kg) $(\mathrm{TBW} / 0.73)(\mathrm{p}<0.0001)\}\{$ Women: baseline $\mathrm{EE}=463.8+20.9 * \mathrm{~B} \ln \mathrm{FFM}(\mathrm{kg})(\mathrm{TBW} / 0.73)$ (p<0.0001); (For Fat: Men: $\{$ baseline EE = 1448.9 + 8.78*Bsln Fat (kg) (p.0038) $\}$ Women: $\{$ baseline $\mathrm{EE}=980.2+11.10 * \mathrm{~B} \sin$ Fat $(\mathrm{kg})(\mathrm{p}<0.0001)\}$ 


\section{Decrease in energy Expenditure from Physical Activity as Dietary Carbohydrate Decreases}

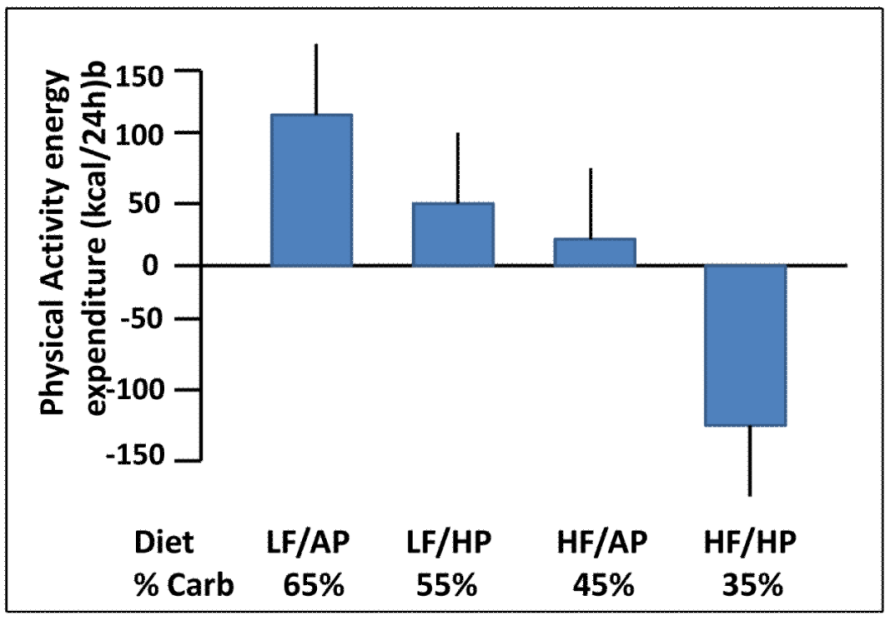

Figure 3.

Relation of Energy Expenditure from Physical Activity to the Prescribed Diet. 
Table 1

Baseline Characteristics for the Participants in the Doubly Labeled Water Sub-study ${ }^{1}$

\begin{tabular}{|c|c|c|c|c|}
\hline & Men & Women & Overall & $\begin{array}{c}P(\text { men vs } \\
\text { women) }\end{array}$ \\
\hline Number & 49 & 50 & 99 & -- \\
\hline White (\%) & $100 \%$ & $84 \%$ & $92 \%$ & $<0.001$ \\
\hline Age (y) & $54.1(8.2)^{*}$ & $52.4(9.8)$ & $53.3(9.0)$ & 0.37 \\
\hline Height (cm) & $176(5.8)$ & $162(6.3)$ & $169.7(9.2)$ & $<0.0001$ \\
\hline Weight (kg) & $105(14.4)$ & $86(12.6)$ & 96. (16.4) & $<0.0001$ \\
\hline BMI $\left(\mathrm{kg} / \mathrm{m}^{2}\right)$ & $33.8(4.00)$ & $32.7(4.18)$ & $33.2(4.11)$ & 0.18 \\
\hline $\begin{array}{l}\text { Surface Area } \\
\left(\mathrm{m}^{2}\right)\end{array}$ & $2.21(0.16)$ & $1.92(0.15)$ & $2.06(0.21)$ & $<0.0001$ \\
\hline $\operatorname{TEE}(\mathrm{kcal} / \mathrm{d}){ }^{l}$ & 3055 (427) & $2464(433)$ & $2760(520)$ & $<0.0001$ \\
\hline $\operatorname{REE}(\mathrm{kcal} / \mathrm{d}) l$ & $1816(223)$ & $1430(197)$ & $1621(285)$ & $<0.0001$ \\
\hline $\begin{array}{l}\text { Non-resting } \\
\text { energy } \\
\text { expenditure } \\
\text { (NREE) }\end{array}$ & $1057(308)$ & 895 (335) & $976(330)$ & 0.023 \\
\hline Activity factor ${ }^{2}$ & $1.58(0.11)$ & $1.55(0.10)$ & $1.56(0.10)$ & 0.14 \\
\hline $\mathrm{FFM}(\mathrm{kg}) l$ & $63.6(6.8)$ & $46.3(6.1)$ & $54.8(10.8)$ & $<0.0001$ \\
\hline Body fat $(\mathrm{kg}) l$ & $41.9(10.3)$ & 40.5 (9.6) & $41.2(9.9)$ & $<0.0001$ \\
\hline Body fat, $\%^{l}$ & $39.3(5.4)$ & $46.3(6.0)$ & $42.8(6.7)$ & $<0.0001$ \\
\hline $\begin{array}{l}\text { Body energy } \\
\text { stores (Mcal) }^{3}\end{array}$ & 457 (100) & 427 (91) & $442(96)$ & 0.12 \\
\hline Food Quotient & $0.834(0.024)$ & $0.842(0.022)$ & $0.838(0.023)$ & 0.10 \\
\hline $\begin{array}{l}\text { Prescribed } \\
\text { energy level of } \\
\text { diet }^{4} \\
\quad(\text { median } \mathrm{kcal} / \mathrm{d})\end{array}$ & 2200 & 1400 & 1800 & $<0.0001$ \\
\hline (mean kcal/d) & $2126(401)$ & 1464 (272) & $1791(476)$ & $<0.0001$ \\
\hline $\begin{array}{l}\text { Prescribed daily } \\
\text { energy deficit } \\
(\mathrm{kcal} / \mathrm{d})^{5}\end{array}$ & $900(340)$ & $989(337)$ & $945(340)$ & 0.19 \\
\hline $\begin{array}{l}\text { Physical activity } \\
\text { level (PAL) }\end{array}$ & $1.69(0.17)$ & $1.73(0.23)$ & $1.71(0.20)$ & 0.26 \\
\hline PAEE (kcal/d) ${ }^{7}$ & $933(277)$ & $792(301)$ & $862(296)$ & 0.027 \\
\hline
\end{tabular}

Abbreviations: $\mathrm{BMI}=$ body mass index; TEE = total energy expenditure; REE = resting energy expenditure; FFM = fat free mass; PAEE = physical activity energy expenditure;

* mean(SD) were determined with the distribution program of JMP; the statistical difference between men and women was determined from a oneway ANOVA.

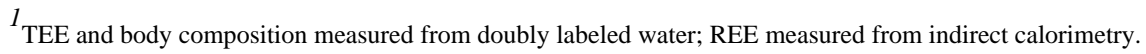
2

2 Activity Factor from Baecke Questionnaire; 
3 Body energy stores calculated as $\{[\mathrm{BF}(\mathrm{kg}) * 9400 \mathrm{kcal} / \mathrm{kg}\}+\{[\mathrm{FFM}(\mathrm{kg})] * 1000 \mathrm{kcal} / \mathrm{kg}\}$

${ }^{4}$ Prescribed energy level of diet $=$ REE times Activity Factor minus $750 \mathrm{kcal}($ minimum $1200 \mathrm{kcal} / \mathrm{d})$

5 Prescribed energy deficit $=$ TEE $($ baseline $)$ minus prescribed energy level of diet

${ }^{6}$ Physical activity level $(\mathrm{PAL})=$ TEE/REE from doubly labeled water and indirect calorimetry

${ }^{7}$ Physical activity energy expenditure $=0.9 \times \mathrm{TEE}-\mathrm{REE}$ from doubly labeled water and indirect calorimetry 

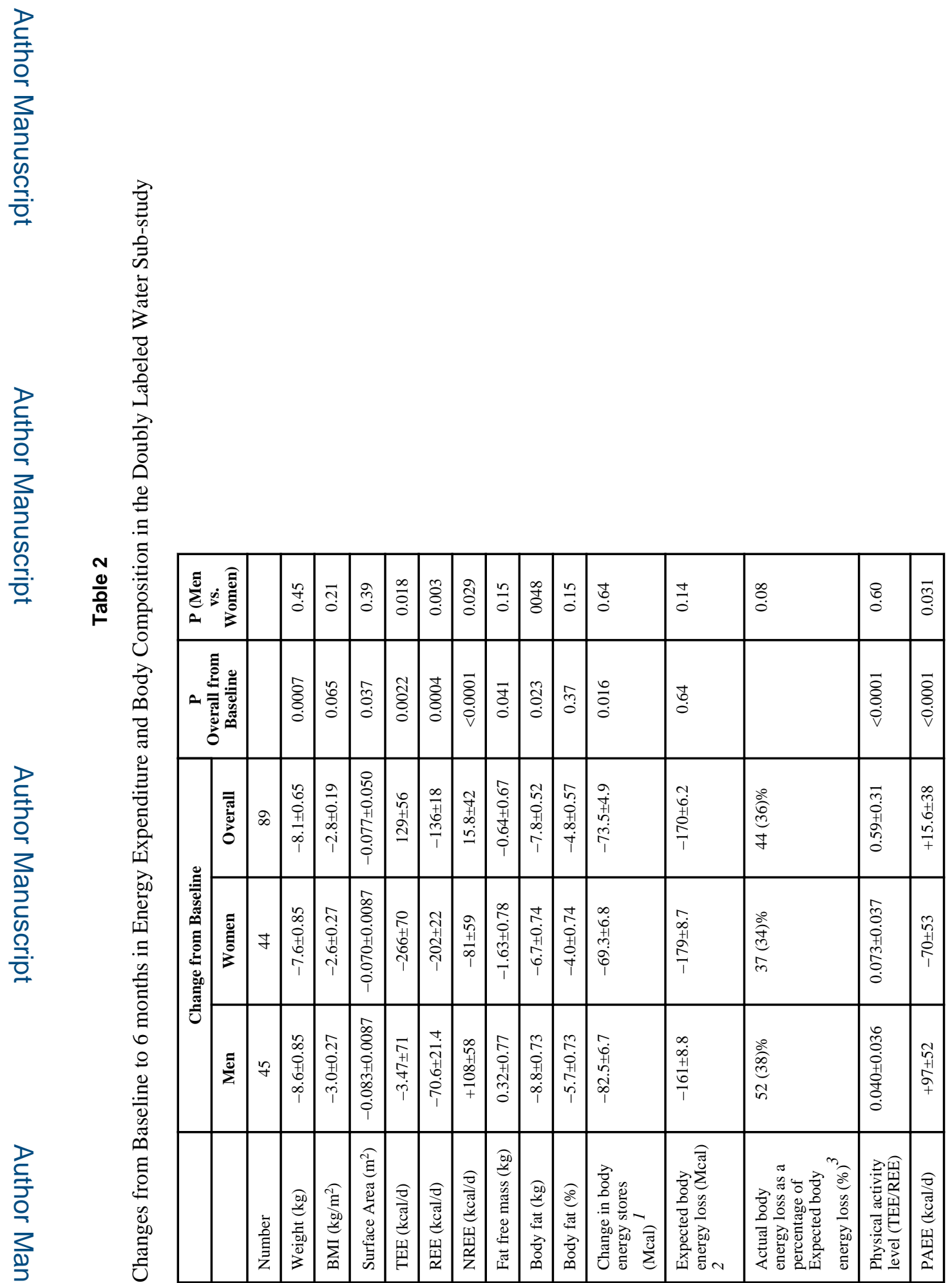


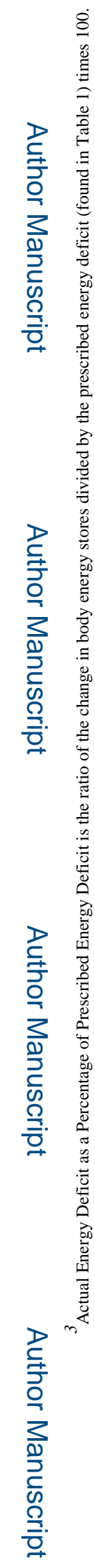

$$
\text { D }
$$

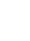

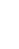
要 흘

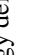


